\title{
Nesting of the Mockingbird at Cadogan, Alberta
}

\author{
by H. W. Burns, Leduc, Alberta
}

On July 12, 1964, Mr. Denis Galloway, of Czar, informed me that a Mockingbird had been reported on the Mr. F. Speight farm, near Cadogan, a small town west of Macklin, Saskatchewan, and we went immediately to investigate. Mr. and Mrs. Speight believed that they had discovered a Mockingbird because it sang most of the night and imitated other birds. Mr. Galloway and I located the nest upon our arrival about 75 yards from the house and 13 feet above the ground in a pine tree in a shelterbelt surrounding the farm buildings. The nest contained five eggs and, as the Speights were not at home, we left a note requesting that they let us know when the eggs were hatched.

On July 18, Mrs. Speight, who has a keen interest in natural history, reported that the eggs had hatched. With two Alberta naturalists, Mr. E. T. Jones and Mr. C. Hampson, I visited the farm on July 21 in order to photograph the birds in their nest. We found the Speights at home, and they stated that they had first noticed the male Mockingbird singing on June 10. They reported that when the yard light was switched on at night the bird would begin to sing. This would go on all night at times. They were sure that both the male and female were there on June 12 , since on that date they had heard at times an answering call when the male stopped singing. Becalise the Speights were busy at the time' they had not been able to notice any nest building.

The nest was composed of dry pine twigs and was lined with rootlets, binder twine, and pasture sage. It contained five young which were fed by the female at 15 minute intervals. She would also brood or shade them for approximately five minutes at each visit (it was a hot day). The principal food appeared to be grasshoppers and smaller insects. We kept the nest under observation for about seven hours, and during this time the male visited the nest with food only once.

Mr. Jones left bands with Mrs. Speight, and asked her to band the young when they were old enough. On August 2 Mrs. Speight reported that this had been done and that the young had left the nest. At the time of writing the young were still present in the shelterbelt.

Mr. Frank Brazier deserves thanks for encouraging me to prepare this report.

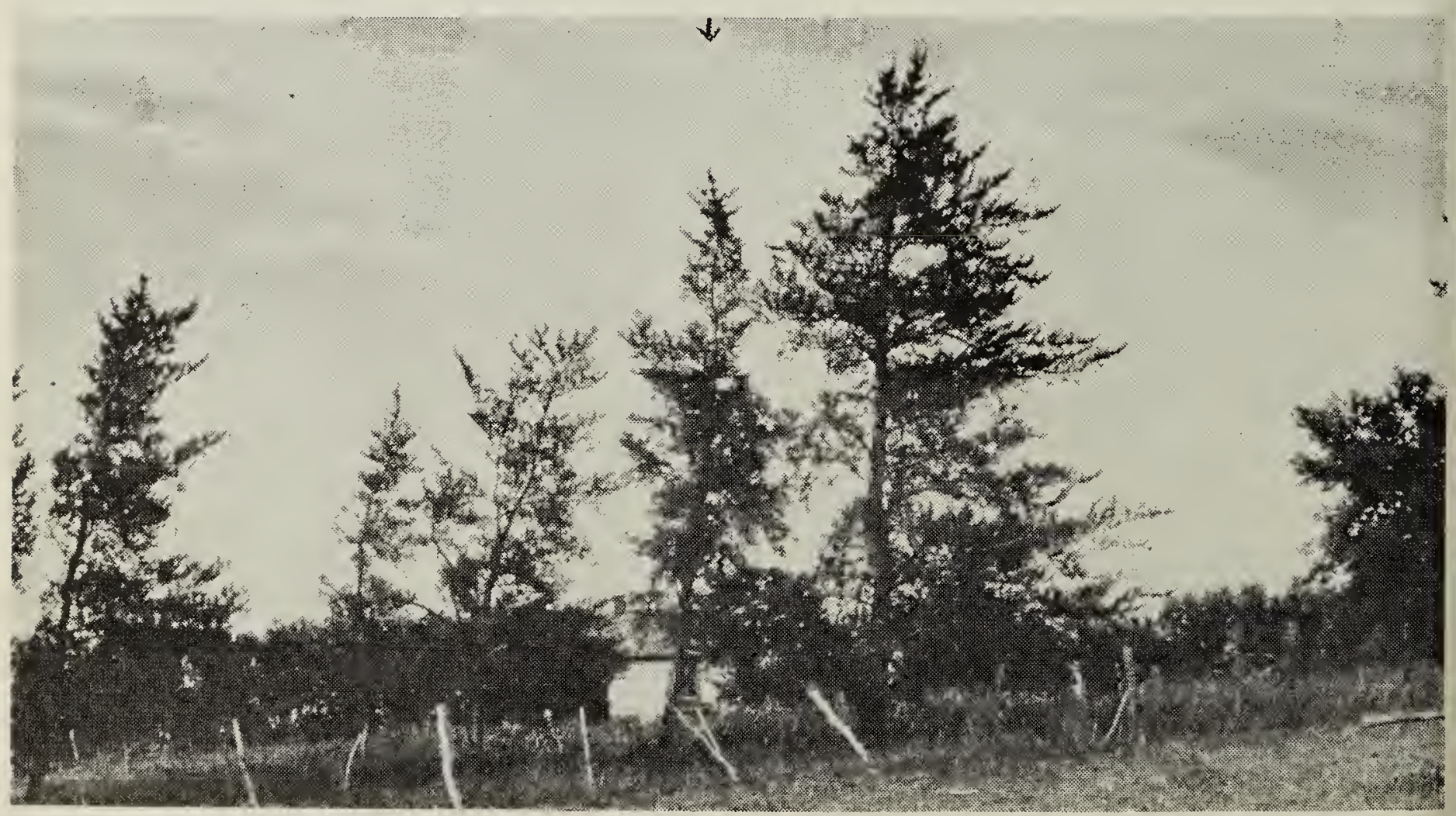




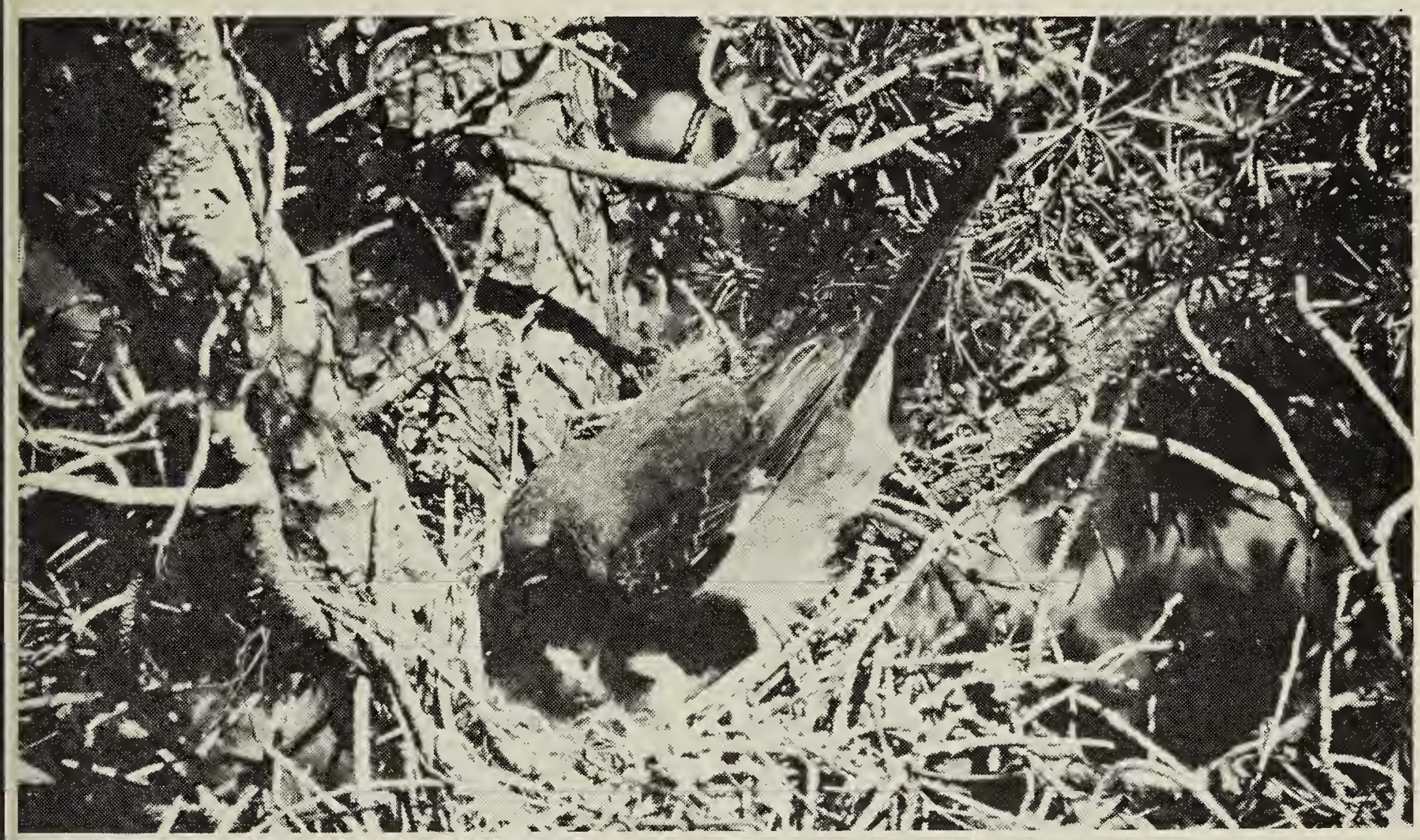

Photo from color transparency by $\mathrm{H}$. W. Burns Mockingbird at nest, Cadogan, 1964.

\title{
Additional Records of the Mockingbird
}

\author{
by Frank H. Brazier, Regina
}

My study "Status of the Mockingbird in the Northern Great Plains" (The Blue Jay, 22:63-75, June, 1964) evoked welcome comment from Harold Hosford, of the Natural History Society of Manitoba, and Ron Huber, of Minneapolis, Minnesota. Mr. Hosford deplored the scanty Manitoba records, particularly as lack of them had led me to report erroneously (p. 68) that the Prince Albert record was the species' farthest north report. He had gone through "Chickadee Notes" (a column in The Winnipeg Free Press, by the late Mr. A. G. Lawrence, and subsequently by Harold Mossop) for many records I did not have. Mr. Lawrence had noted that in Manitoba quite a flurry of records had occurred in the late 1920's but no nest was found and the invasion petered out. A similar situation prevailed in the entire region as the records shown in Table 2 of my previous report reveal.

Ron Huber obligingly culled Mockingbird records from The Flicker (now The Loon) for additional records to bring those for the easternmost part of the Northern Great Plains up to date. I wish to record my indebtedness to both these SNHS members.
I have not included a recent Alberta breeding record in this article as it appears elsewhere in this issue.

\section{ADDITIONAL RECORDS}

1922. 1 seen at KENTON, Man., by Dr. J. E. Tisdale, Manitoba's first record. (Chickadee Notes \#1755, Jan. 8,1955 , cited by $H$. Hos. ford).

1950. 1 seen at STEEPROCK, Man., May 28, by A. Isfeld of Benito, Man. (Chickadee Notes \#1515, June 3, 1950, cited by H. Hosford). Note: Steeprock River is said to be 70 miles north of Swan River, Man., but this is evidently a misprint as Steeprock Creek on current maps is 40 miles north of Swan River.

1954. 1 seen at WINNIPEG, Man., by A. G. Lawrence at local feeding station Dec.-Jan. 3, 1955. (Chickadee Notes \#1755, Jan. 8, 1955, cited by $\mathrm{H}$. Hosford).

1955. 1 seen at CHURCHILL, Man., May 31, by Mrs. A. Beckett (continent's farthest north record). (Chickadee Notes \#23, June 17, 1955, cited by H. Hosford). 